\title{
A difusão vertical na web social: o caso de "Heaven Can Wait" no Antville
}

\author{
João Pedro da Costa
}

\begin{abstract}
Resumo
Introdução: Procede a uma análise textual da fruição participativa do Antville, a mais antiga e maior comunidade virtual de fãs do formato videomusical, à Heaven Can Wait de Charlotte Gainsbourg \& Beck (2009). Método: Utiliza uma aplicação da teoria fundamentada em dados ao método etnográfico. Resultados: Os resultados principais da análise passam pelo enquadramento da referida praxis dos membros do Antville num tipo de fruição participativa "forense" geradora de uma forma eloquente de inteligência coletiva que, motivada por características producentes do texto videomusical. Conclusões: A estrutura verificada desencadeia um tipo de difusão passível de ser conceptualizada como "vertical", isto é, como uma forma complementar das práticas difusoras "horizontais" mais comuns na web social (disseminação e propagação).
\end{abstract}

\section{Palavras-chave}

Web social. Vídeo musical. Difusão vertical na web. Difusão horizontal na web. Cultura dos fãs.

O vídeo musical realizado por Keith Schofield para o tema Heaven Can Wait de Charlotte Gainsbourg (atriz e cantora anglo-francesa, filha da atriz francesa Jane Birkin e do cantor, compositor e realizador Serge Gainsbourg) \& Beck (cantor, compositor e multi-instrumentista norte-americano), foi carregado para o Vimeo no dia 19 de novembro de 2009 (HEAVEN..., 2009a) e para o YouTube no dia 10 de abril de 2010 (HEAVEN..., 2009b) ${ }^{1}$. Em abril de 2014, os referidos intertextos tinham atingido 407 mil e 1,15 milhões de visualizações nos respectivos portais, totalizando cerca de 1,6 milhões visualizações na web social, valor manifestamente elevado para um projeto musical indie $^{2}$. No entanto, o acesso ao vídeo musical já tinha sido anteriormente disponibilizado no blogue do Antville, a maior e mais antiga comunidade virtual de fãs do formato videomusical, no dia 18 de novembro de 2009 , tendo desencadeado uma acesa discussão entre diversos membros da comunidade que publicaram, até à referida data, 193 comentários na caixa do respectivo post ${ }^{3}$.

Quadro 1 - Carregamentos iniciais de Heaven Can Wait na web social

\begin{tabular}{llll} 
plataforma & $\begin{array}{l}\text { tipo de rede } \\
\text { social }\end{array}$ & utilizador & data \\
Antville & blogue & captainmarc22 & 18/11/2009 \\
\cline { 2 - 4 } Vimeo & $\begin{array}{l}\text { portal de } \\
\text { partilha de } \\
\text { videos }\end{array}$ & $\begin{array}{l}\text { Charlotte } \\
\text { Gainsbourg }\end{array}$ & 19/11/2009 \\
\cline { 2 - 4 } YouTube & $\begin{array}{l}\text { portal de } \\
\text { partilha de } \\
\text { videos }\end{array}$ & Keith Schofield & 10/04/2010 \\
\cline { 2 - 4 } MySpace & $\begin{array}{l}\text { portal de } \\
\text { partilha de } \\
\text { música e }\end{array}$ & Charlotte & Gainsbourg \\
videos & &
\end{tabular}

Fonte: o autor, 2014.

\footnotetext{
${ }^{1}$ Uma possível explicação sobre a preferência dada ao Vimeo em detrimento do YouTube pode estar relacionada com os diferentes níveis de acessibilidade, usabilidade e desejabilidade dos dois portais (COSTA, 2010). O vídeo musical foi igualmente carregado para o MySpace, mas está atualmente indisponível.

${ }^{2} \mathrm{Ou}$ independente, termo popularizado no início dos anos 80 nos Estados Unidos e que se referia inicialmente aos projectos musicais sem contrato discográfico com as seis grandes editoras discográficas da época: EMI, CBS, BMG, PolyGram, Warner e MCA. Devido ao facto de as referidas majors privilegiarem um tipo de música supostamente mais comercial ou mainstream, o termo indie passou, por metonímia, a designar igualmente uma sensibilidade musical transversal a diversos géneros, com predominância para o rock (também designado de "alternativo"). É, no entanto, importante ter sempre em conta que é bastante comum que uma música considerada indie ou alternativa por uma geração, cena local ou mercado poder ser adotada ou percebida por outro grupo como sendo mainstream ou comercial (TAYLOR et al., 2013, p. viii).

${ }^{3}<$ http://videos.antville.org/stories/1948117>. Um trailer do vídeo musical tinha sido publicado previamente no blogue da comunidade no dia 5 de outubro de 2009: <http://videos.antville.org/stories/1936215>. Acessos em: 16 abr. 2014.
} 
O referido post (Figura 1) possui uma estrutura similar aos restantes que povoam o blogue da comunidade: o título inclui uma descrição do projeto musical (uma colaboração entre Charlotte Gainsbourg e Beck), o título do vídeo musical (Heaven Can Wait) e o nome do realizador (Keith Schofield); o corpo do post, por sua vez, inclui três imagens do vídeo musical e uma hiperligação para o portal do realizador. A habitual incorporação (ou widgetização) de um intertexto do vídeo musical oriundo dos portais de partilha de vídeos era, à data, impossível, na medida em que - como foi referido - Heaven Can Wait apenas viria a ser carregado um dia depois para o Vimeo e cerca de cinco meses depois para o YouTube e o MySpace. Significativo, no entanto, é o fato de a hiperligação incluída no post remeter para uma página do portal do realizador cujo URL não estava, à data, publicado ou sequer acessível a partir da página de entrada (ou de qualquer outra página) do referido portal, o que indicia que o utilizador@captainmarc22 teria alguma ligação com a equipe responsável pela produção do vídeo musical ou, pelo menos, com a indústria videomusical $^{4}$. É por isso que o anterior carregamento de Heaven Can Wait numa página "escondida" do portal de Keith Schofield não pode ser considerado a primeira integração do vídeo musical na web social: a sua insularidade foi apenas quebrada com a publicação do respectivo URL no referido post do Antville.

O interesse demonstrado pelos membros da comunidade Antville em relação a Heaven Can Wait estava diretamente relacionado com a carreira fulgurante de Keith Schofield no universo videomusical. Em apenas cinco anos, o realizador norte-americano já tinha dirigido quase duas dezenas de vídeos musicais, entre os quais se destacam os de Bad Blood dos Supergrass (vencedor do prêmio para melhor vídeo rock dos UK Video Awards de 2008), Toe Jam dos The BPA (nomeado pelo Antville para a sua lista dos 50 melhores vídeos da última década) e Let Love Rule dos Justice e Lenny Kravitz (um dos cinco nomeados para o prêmio de melhor vídeo musical dos Vimeo
Figura 1 - Captura de tela do post relativo à Heaven Can Wait no Antville

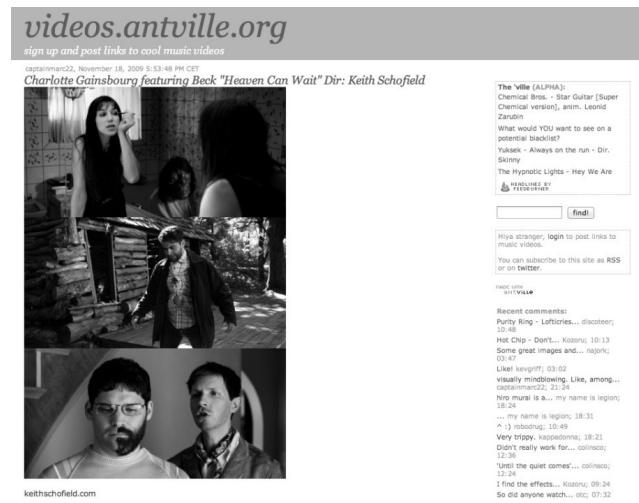

Fonte: o autor, a partir de <http://videos.antville.org/stories/1948117>.

Awards 2010). Heaven Can Wait era igualmente o primeiro trabalho de Keith Schofield após o spot publicitário da sua autoria intitulado Diesel SFW $X X X$ ter sido premiado em dois dos mais prestigiados festivais internacionais de publicidade: os British Television Advertising Awards (Reino Unido) e o Cannes Lions (França). A expectativa do Antville relativamente ao próximo capítulo da carreira do realizador estava, por isso, ao rubro.

Heaven Can Wait é, sem dúvida, uma obra singular. Ao longo dos 2 minutos e 40 segundos da sua duração, o vídeo musical desfila um conjunto de 50 cenas insólitas muito curtas (todas com menos de 4 segundos) sem nenhuma relação aparente entre si, a não ser o fato de todas incluírem diversas personagens (entre elas, Charlotte Gainsbourg e Beck); de serem riquíssimas na sua composição (enquadramento, cenário, personagens e guarda-roupa); e de a maioria ser reproduzida em câmara lenta. Apesar do recurso a essa técnica é impossível apreender a totalidade dos detalhes e dos diferentes fios narrativos sugeridos pelas várias cenas em uma única visualização. Uma breve tentativa de descrição das primeiras cenas (algumas delas recorrentes) (HEAVEN..., 2009a: 0'00"-0'52") exemplifica não apenas a heterogeneidade como a singularidade da série:

a) diversas pessoas a dormir em sacos-cama em torno de Charlotte Gainsbourg que olha para Beck a tocar guitarra;

\footnotetext{
${ }^{4}$ Este indício é confirmado pelo próprio @captainmarc22 (um dos membros mais activos da comunidade) num comentário a um post publicado no blogue no dia 5 de abril de 2005: «I have worked with directors and bands in videos that have been posted here [on Antville]»: <http://videos.antville.org/stories/1089368/\#1090194>. Acesso em: 16 abr. 2014.
} 
b) um b-boy a executar um número de break dance no passeio de uma rua;

c) uma partida de tênis com diversos jogadores e bolas a atravessarem simultaneamente o campo;

d) Charlotte Gainsbourg sentada à beira de uma piscina com os pés na água e Beck ao lado a tocar guitarra;

e) um jovem casal a correr numa praia com o rapaz a empunhar uma espada;

f) Charlotte Gainsbourg maquiando-se ao espelho de uma casa de banho enquanto um monstro (que parece saído do filme Guerra nas Estrelas) está sentado na banheira;

g) uma colcha a levitar no centro da sala de jantar repleta, em um restaurante;

h) Charlotte Gainsbourg a embalar um bebê vestido de cachorro-quente;

i) duas adolescentes a testar uma carabina numa loja de armas e munições;

j) Charlotte Gainsbourg e um casal idoso a exibirem um prato com o que parece ser uma montagem de frutos e vegetais com a forma de um mocho;

k) um latino-americano a pentear a sua poupa cheia de gel ao lado de outro que tem nas mãos uma noz gigante do tamanho de uma abóbora;

1) uma criança obesa em tronco nu com uma guitarra a dançar aos saltos perante a indiferença de Beck e de um casal de idosos;

m)dois adultos a olhar um para a outro sorridentes enquanto exibem uma bomba que ostenta a palavra "nachos" escrita a giz;

n) uma prancha de skate pousada em cima de quatro pilhas de hambúrgueres;

o) um casal a deslocar-se num veículo de golfe a alta velocidade (o traje do elemento feminino parece saído de Alice no País das Maravilhas);

p) Charlotte Gainsbourg a almoçar com mais cinco pessoas (uma delas tem como cabeça um crânio bovino); q) uma idosa a acertar com um taco de basebol numa laranja que lhe é atirada.

À primeira vista, pouco parece fazer "sentido" neste vídeo musical - e esse "pouco" resume-se praticamente à edição síncrona dos planos com as batidas da trilha sonora ${ }^{5}$ e à presença recorrente de Charlotte Gainsbourg e Beck (estão lá porque, de fato, são eles os intérpretes do tema musical). Devido à sua elevada "porosidade", o vídeo musical enquadra-se, definitivamente, na categoria dos textos producentes (FISKE, 1992, p. 104), na medida em que cada um dos seus planos não apenas permite como parece convidar de forma urgente a participação das audiências na produção do(s) seu(s) hipotético(s) sentido(s).

No entanto, Heaven Can Wait não se limita a esse apelo e fornece igualmente duas pistas cuja legibilidade é elevada junto dos seus potenciais fruidores (consumidores de música indie e fãs do formato videomusical). As referidas pistas consistem em cenas que contêm evidentes relações hipertextuais (GENETTE, 1982) a conhecidos hipotextos da cultura popular: um quadro de Magritte e a capa de um disco da banda Led Zeppelin (Figura 2).

Como interpretar as pistas de leitura oferecidas pelas referências explícitas (ou paródias) a dois hipotextos sedimentados da cultura popular? A alusão ao quadro de Magritte pode ser interpretada como uma chave de leitura que aponta para uma aplicação da escrita automática surrealista ao domínio da produção videomusical, como explica Breton:

Placez-vous dans l'état le plus passif ou réceptif que vous pourrez [...] Écrivez-vite sans sujet préconçu, assez vite pour ne pas vous retenir et ne pas être tenté de vous relire (BRETON, 1994, p. 41).

Heaven Can Wait aparenta, de fato, encaixar-se nas características das criações surrealistas: a série heterogênea de cenas não apenas não parece ter qualquer unidade temática ou qualquer relação com a letra do tema, como possui um conjun-

\footnotetext{
${ }^{5}$ No entanto, a edição não é regular, isto é, a mudança de planos não acompanha o compasso quaternário 4/4 da canção. É por isso que as cenas não têm a mesma duração.
} 
Figura 2 - Captura de duas imagens de Heaven Can Wait com sobreposição dos respectivos hipotextos
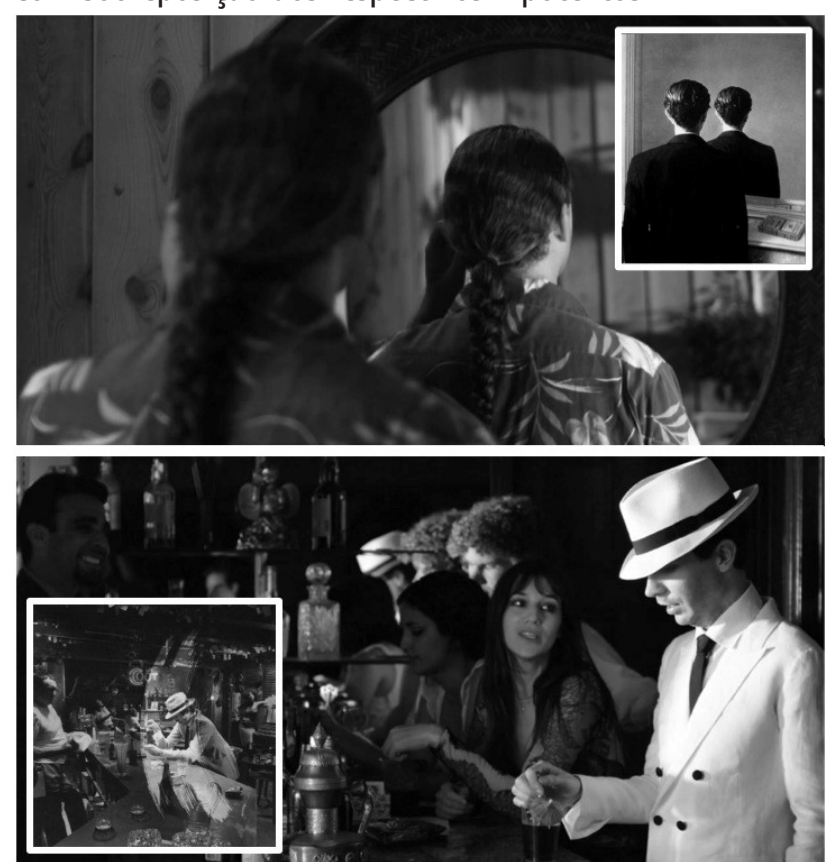

Fonte: o autor, a partir de <http://videos.antville.org/stories/1948117>

to de características insólitas, que apontam para uma dimensão onírica ancorada no subconsciente do seu realizador. No entanto, a segunda referência hipertextual à capa de um álbum da banda Led Zeppelin parece também indiciar uma prática potencialmente recorrente de emulação de hipotextos da cultura popular e legitima uma série de interrogações no âmbito da leitura "excessiva" (FISKE 1992, p. 104) do vídeo musical: serão todas as cenas incluídas em Heaven Can Wait igualmente alusões e, em caso afirmativo, a que hipotextos?

É um percurso relativamente análogo ao que foi aqui exposto o que é levado a cabo por dezenas de membros da comunidade Antville na impressionante sequência de 193 comentários ao post em que o vídeo musical foi pela primeira vez disponibilizado na web social. Os primeiros comentários referem a aparente aleatoriedade da série de cenas que compõem Heaven Can Wait:

Not sure I understood what it was going for, but the footage do looks beautiful.

(@captainmarc22)

Surely you could throw a dart and fill those frames. (@senility_now)
Definitively some cool imagery, but so random. Doesn't feel like any effort was made to link it all together. (@captainhairy)

Outro aponta mesmo para a sua natureza "porosa", comparando-o com um dos mais populares formatos mediáticos producentes, os trailers cinematográficos:

The randomness - It helps if you pretend that this is a trailer to a bat-shit crazy movie. LOVE that shot with the guy on the field running from the axe. I want to see that movie.

(@birds.on.fire)

E um, em particular, alude aos aparentes efeitos surrealistas da sua concepção:

This is the best video ever made, I feel like my mind has been scooped.

(@tobiasstretch)

No entanto, à medida que se desenvolve o diálogo na caixa de comentários, o utilizador @my_name_is_legion sugere uma pista que é, de imediato, seguida por outros membros da comunidade:

This video looks too random, like the director spent too much time looking through his FFFFOUND! folder.

(@my_name_is_legion)

Legion's on to something [...] It's almost as if Keith's had this idea of making a cinematic montage of his favorite internet/art images for a while, and he just started saving them in a folder on his computer - and now... voilà. What if we found out that each shot was a homage to some image?

(@Bunny_Greenhouse)

Very nice. Obviously it's a homage to Keith's favorite FFFFOUND! Images and I think Bunny Greenhouse is right [...] [when he says] this makes the video far more interesting conceptually.

(@kansas)

A referência ao FFFFOUND! ${ }^{6}$ é particularmente pertinente, na medida em que esta plataforma da web consiste num marcador social (social bookmarker) que utiliza um algoritmo para sugerir e recomendar imagens que possam interessar a um determinado utilizador, consoante à sua classificação popular (folksonomy) levada a cabo 
pelos membros da comunidade. O que os membros do Antville fazem na sequência é precisamente identificar, uma a uma, a quase totalidade do vasto conjunto de hipotextos de cada uma das cenas hipertextuais de Heaven Can Wait.

A Figura 3 apresenta oito das muitas cenas cujos hipotextos foram identificados pelo Antville. Esta genuína performance coletiva (SUROWIECKI, 2004) foi motivada, por um lado, pela natureza "porosa" do texto producente de Heaven Can Wait e, por outro, pela presença de pelo menos duas referências hipertextuais bem legíveis que indiciava a potencial existência de um hipotexto para cada uma das cenas. A identificação destes hipotextos foi sucessivamente levada a cabo por diversos membros da comunidade, recorrendo à sua memória individual ("onde é que já vi isto?"), às pistas e sugestões lançadas pela comunidade e às ferramentas (marcadores sociais, motores de pesquisa etc.) que a web social coloca à sua disposição. Tal praxis enquadra-se de forma particularmente aguda na famosa noção de inteligência coletiva definida por Pierre Lévy:

Figura 3 - Captura de imagens de Heaven Can Wait com sobreposição dos respectivos hipotextos identificados pelo Antville
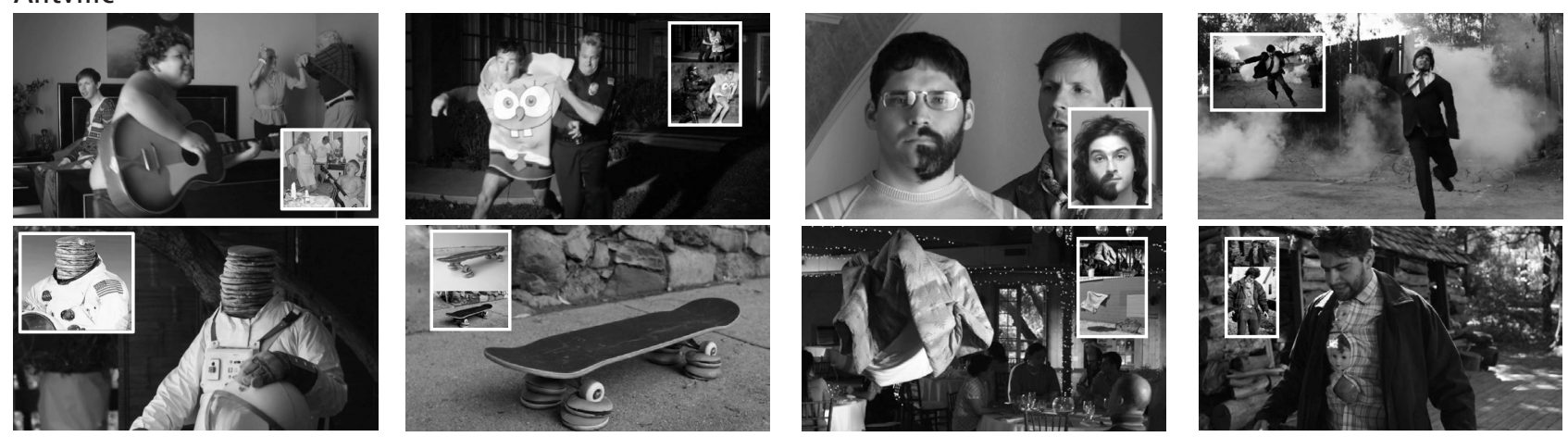

Fonte: o autor, a partir de <http://videos.antville.org/stories/1948117>.

The members of a thinking community search, inscribe, connect, explore... Not only does the cosmopedia make available to the collective intellect all of the pertinent knowledge available to it at a given moment, but it also serves as a site of collective discussion, negotiation and development. Unanswered questions will create tension within cosmopedic space, indicating regions where invention and innovation are required (LÉVY, 2007, p. 217, grifo nosso).

O empenho da fruição participativa dos membros da comunidade Antville demonstra igualmente que certos conteúdos mediáticos, como o vídeo musical de Heaven Can Wait, suscitam uma prática difusora distinta das mais comuns na web social (disseminação e propagação) ${ }^{7}$ e que Jason Mittell nomeia drillability:

Perhaps we need a different metaphor to describe viewer engagement with narrative complexity. We might think of such programs as drillable rather than spreadable. They encourage a mode of forensic fandom that encourages viewers to dig deeper, probing beneath the surface to understand the complexity of a story and its telling. Such programs create magnets for engagement, drawing viewers into the storyworlds and urging them to drill down to discover more (MITELL, 2009).

No caso de Heaven Can Wait não é a complexidade (de resto, inexistente) dos seus meros esboços micronarrativos, mas sim a natureza producente do seu texto videomusical que desencadeia a fruição participativa forense dos membros do Antville que investigaram, colectivamente e com assinalável eficácia, as origens hipotextuais da quase totalidade das suas cenas. Este tipo de fruição origina uma variante difusora que pode ser, recorrendo a uma metáfora euclidiana, caracterizada como vertical, não apenas porque permite conceptualizar uma complementaridade axial com as práticas horizontais mais comuns de difusão

${ }^{6}<$ http://ffffound.com>. Acesso em: 16 abr. 2014.

${ }^{7}$ No modelo conceptual de difusão na web social desenvolvido no projeto de investigação doutoral que está sendo levada a cabo, pelo autor, na Faculdade de Letras da Universidade do Porto e no Departamento de Comunicação e Arte da Universidade de Aveiro subordinado ao título A convergência dos vídeos musicais na web social: Conceptualização e Análise. A “disseminação” designa as práticas difusoras operadas pelos utilizadores sem transformação do conteúdo difundido e a "propagação" as que, pelo contrário, implicam uma transformação textual (paródias, pastiches, remisturas, colagens etc.). 
operada pelos utilizadores (ver Quadro 2), mas porque invoca igualmente a pertinente noção de transtextualidade vertical de John Fiske:

Vertical [transtextuality] is that between a primary text, such as a television program or series, and other texts of a different type that refer explicitly to it. These may be secondary texts such as studio publicity, journalistic features, or criticism, or tertiary texts produced by the viewers themselves in the form of letters to the press, or, more importantly, of gossip and conversation (FISKE, 2011, p. 107-108).

Como é óbvio, a difusão vertical do vídeo musical promovida pelos epitextos (comentários ao post) publicados no Antville potencializa igualmente a sua difusão horizontal (disseminação e propagação): inúmeros membros do Antville terão fruído Heaven Can Wait motivados pela discussão que o vídeo gerou nos membros da comunidade (a própria interface do blogue destaca os últimos comentários publicados através de hiperligações na coluna da direita). De resto, a relação dialética entre a difusão horizontal e vertical de conteúdos mediáticos na web social torna ainda mais pertinente e operativa a proposta de uma conceitualização binária das práticas difusoras dos seus utilizadores.

Quadro 2 - Tipologia da difusão na web social

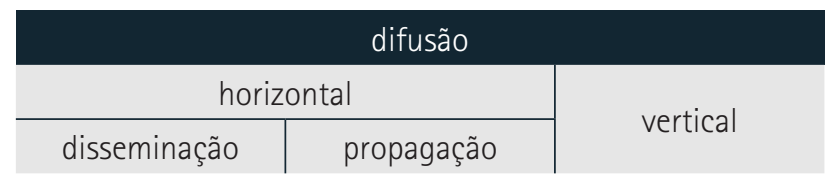

Fonte: o autor, 2014.

O nível argumentativo e a profundidade de algumas das reflexões levadas a cabo pela fruição participativa forense de Heaven Can Wait por parte da comunidade Antville são igualmente merecedoras de uma atenção especial, na medida em que demonstram a "profundidade" da sua difusão vertical.

O primeiro exemplo remete para um comentário do utilizador@wing que consegue a proeza de, em poucas linhas, estabelecer uma muito pertinente relação entre a curta duração dos planos de Heaven Can Wait e a capacidade de atenção (attention span) dos utilizadores da Web; articular uma conceptualização do vídeo musical en- quanto ponte entre as práticas artísticas de baixa-fidelidade $($ low $f$ ) e a arte erudita (high art); propor a referida conceitualização como um eco do trabalho musical de um dos seus intérpretes; e, finalmente, referir a propensão hipertextual do vídeo como um dos argumentos centrais para a sua valorização estética:

Great work! Exquisite cinematic scenes for the attention span of an Internet audience. Perfect execution of low- $f$ meets high art, which is what Beck has been doing musically since 1994. Really like how this is fantastic to look at: it speaks conceptually about things outside each scene. (@wing)

O segundo exemplo prende-se com a discussão que se gera devido ao fato de pelo menos dois dos hipotextos identificados de Heaven Can Wait serem da autoria do fotógrafo William Hundley:

A lot of William Hundley: www.todayandtomorrow.net (@atmc)

O que se assiste a seguir é a cisão dos membros da comunidade em relação à suposta intenção (tópico sempre movediço): que terá movido Keith Schofield a recriar algumas fotografias de William Hundley no vídeo musical: plágio ou homenagem? Os comentários que defendem a primeira hipótese são, como seria de esperar, os mais acintosos:

I don't understand, why throw in rips from Hundley if you obviously spent hours thinking of the most random shit possible?

(@senilitynow)

I [...] have a problem with directors/filmmakers/artists taking what should exist as merely the seed of an idea and instead of embellishing it and taking it to a conceptually-evolved place prefer to merely plunk said image(s) into a larger piece without any context or tact. While this very well may be the point of this video I really feel this approach is not only easy, but lazy, and a ultimately sad comment on the current state of ideas/creativity in general.

(@chupacabraface)

Talent borrows, genius steals? Apparently so; I hope none of the source photos were done by aspiring directors. That would be a drag.

(@jesse.ewles) 
Here's a concept: Let's JUST STEAL IDEAS WITHOUT ATTRIBUTION! So lame. I'd rather see that video directed by any of the people who had those ideas in the first place. I'm guessing Hundley would have loved to have done it. Instead some dickhead does his own version of Hundley. BOO HISS! I'm against it. (@merkley)

merkley \& chupacabraface: Keith Schofield is an obscene hack. Kudos for pointing out his baseless and amoral video. Both of you display enviable courage to tackle and destroy a fraud that is slowly corrupting this industry and the country.

(@vamarishnu)

James Joyce appropriating homer is quite a different thing than this music video director recreating the work of an emerging photographer. For appropriation to function properly, the audience has to be in on the joke... The problem here is that most people won't look at this video and think "oh he's paying homage to Hundley et al.". This video is aimed at an indie music audience, most of whom probably aren't familiar with Hundley's work.

(@jennifer_jordan)

I just emailed Hundley and he had no idea his images were so blatantly ripped. [...] You people making excuses for this hack are doing nobody any good. Get on board or get out of the way. Schofield has the audacity to put himself in the ranks with Spike Jonze and others. HE IS AN EFFING HACK!

(@merkley)

O e-mail enviado por @merkley a William Hundley origina um post do fotógrafo no seu Flickr que é de imediato reproduzido pelo mesmo membro do Antville num comentário:

Someone is using my ideas. Looks familiar? [hiperligações para uma imagem do vídeo e respectivo hipotexto da sua autoria, inserção nossa] Also, there is a floating fabric form in this video very similar to my work. Help me spread the word that Keith Schofield apparently can't come up with his own ideas or at least give me some credit...

(@merkley)

No entanto, um número considerável dos membros da comunidade não subscreve a acusação de plágio que é dirigida a Keith Schofield:

Nothing is original. Steal from anywhere that resonates with inspiration or fuels your imagination. Devour old films, new films, music, books, paintings photographs, poems, dreams, random conversations, architecture, bridges, street signs, trees, clouds, bodies of water, light and shadows. Select only things to steal from that speak directly to your soul. If you do this, your work (and theft) will be authentic. Authenticity is invaluable; originality is non-existent. And don't bother concealing your thievery-celebrate it if you feel like it. In any case, always remember what Jean-Luc Godard said: It's not where you take things from; it's where you take them to. - Jim Jarmusch

(@bryanmatic)

Jarmusch and designers like Ian Anderson are spot on in their analysis of the idea of appropriation. Concepts are not sacred; remakes and covers are standard fare and always have been. Remember that this is not a case of someone using another's artwork directly. It's a reinterpretation and it's a damn good one. Hundley should meet someone who's had their work genuinely stolen. Dude sounds like a priss.

(@familiar)

Recreating these photos was obviously the concept. There is no pretense here, this is ffffound in the video. Consider it homage - Romanek style.

(@trans_alt)

Ironically, Hundley's work is best known because it's been reposted a bazillion times on tumblrs and design sites, often contextless and without credit. I've seen his pictures a few times on different sites and assumed they were simply Internet memes. I suspect Keith thought that same thing, as he referred to them as "found photos" in his treatment. I mean: c'mon, if you see a picture of a skateboard resting on cheeseburgers, I can't blame you if you think its just some silly picture that gets posted on funny picture message boards. And yes, Hundley does sound like a total whiner and opportunist.

(@budget)

This video is far from stealing. This is Keith bringing together some of his favorite ffffound images on tour for everyone to see. If you're included, thank your curator. Keith Schofield has been open about his use of fffound. com and other sites in interviews over the last few years. I'm sure he has introduced this site to some of you. Part of the reason why Keith has done so well in the viral world is because he fully embraces the concept of the Internet as a shared place. He is one of the few directors out there who openly post most of his treatments on his site for everyone to view. He explains and reveals many of his techniques for others to study and yes copy.

(@lameaholic)

Somebody above posted about intent. Personally, I think the video is absolutely about a certain randomness that makes sense to the creator. In interviews, Schofield has himself said that the way he concepts is by looking at a photo collection and seeing what sticks. It's a logical approach. Many directors do this. In this case the idea was 
especially about that. Why does the creator have to clue the audience into context? I have no doubt that he knew whose images he was tipping his hat to, but I think he was doing it with the best of intentions. Though I will say it's a bit odd that none of these ref images appear in the actually treatment. I wonder if Beck and Charlotte would've agreed had they seen the originals. Again, I can empathize with the photographer, but this calling Keith a hack is just silly. He is clearly a creative guy whose work is consistent in attitude and execution. Some people need to re-read Walter Benjamin's Art In the Age of Mechanical Reproduction. Three Words: Andy Fucking Warhol. And I for one recognized the image homage on first watch and thought that was half the fun. Nice one mate.

(@quixoticnyc)

A série de argumentos invocados nestes comentários leva William Hundley a registar-se na comunidade Antville para publicar um texto que de certa forma emenda o tom mais inquisitório do seu post anteriormente publicado no Flickr:

I don't think it was malicious, but he should have contacted me. I understand that this kind of stuff happens all the time and will continue to happen, but that doesn't make it right. I am not a priss, but I am broke. It just sucks to see someone financially gain by using my ideas (and others) without giving any credit or compensation. I try and see the good and positive in all situations and I appreciate everyone's input/feedback on this. Anyone that sees this video and is not familiar with my work will credit the director for the visuals and they will never know my work. How can I see that from a positive perspective?

(@williamhundley)

A discussão procede nos moldes e tom descritos: ambas as partes apresentam os seus argumentos, hiperligam entrevistas ao realizador e a outros hipotéticos hipotextos de Heaven Can Wait, citam autores que legitimam as suas posições etc. Isto até que, no dia 25 de novembro de 2009 (isto é, uma semana após a publicação do post), Keith Schofield (também ele membro do Antville) publica um longo comentário em que conta a sua versão dos acontecimentos. A transcrição de longos excertos do texto justifica-se pelo fato de o mesmo articular, com grande loquacidade, a história da produção do vídeo musical, os diferentes argumentos invocados pelos membros da comunidade Antville, a visão do realizador sobre o espaço colaborativo que é a Internet e até um mea culpa por não ter creditado William Hundley nas duas cenas inspiradas nas suas fotografias. No fundo, o seu comentário funciona como uma genuína sinopse epitextual deste caso de estudo (as hiperligações do original são omitidas na reprodução):

First off, I wanted to say I read Antville everyday and I'm a huge music video fan. After toiling in obscurity for years, I can't tell you how happy I was when my videos started receiving more than a handful of comments. People always argue about good and bad work; but the worst thing that can happen to a video is it gets ignored. So, positive and negative comments, I'm glad people are watching. Anyway, this video has sparked a long conversation and I owe it to everyone to tell my side of the story. So here it is [...].

I've been a fan of found photos for a long time. In the pre-Internet area, a found photo was a snapshot you might find at a thrift store or flea market. It was some random family photo, of people you've never known from some bygone era. The appeal of the photo is the mystery. Why was it taken? Where are these people now? Why was this photo abandoned? Often, finders would be left to imagine their own stories. Online found photos have evolved to cover all sorts of imagery: scanned photos, digital photos, photoshops, video stills, advertisements, art projects. But it's the same appeal - there is no context, and thus the viewer is left to imagine his own backstory. The first site I found years ago was called 'what a quiet stiff.' It was the found photo collection of a Ruby programmer called_why. He unfortunately removed his entire archive online a few months ago; but I fortunately downloaded his entire collection. [...] What I loved about_why's site was that it was all very amateurish. Heavy on kitsch and tackiness. Look at the images of bad 3D. Or hilarious kid's drawings. Or bizarre photoshops.

And as I began my music video career, I looked through his site looking for inspiration [...] and as I continued to pitch on videos, I found myself scouring the Internet for new sources of found photos - like ffffound.com, and foundphotos (which scans file sharing networks for people's personal photos). [...] Found photos have even gone low-brow with fun (yet junky) sites like Explain this Image and Picture is Unrelated. [...] I have about 3000 photos in a big folder on my desktop. Often when I get a music track in, I'll scroll through the pictures and see if anything sticks. However, most of these images - as amazing and quirky as they are - aren't really the basis for a 3 minute music video. A photo like this is amazing... [...] but what are you going to do with it? The whole band playing instruments with doll heads in their shirts? That's not a good idea.

And so, about a year ago, I was flipping through my folder while listening to a song, and I thought: the best music video in the world would be one where it was just a series 
of incredible, surreal scenes. Each scene would be vastly different, and we would never repeat the same scene. In July of this year, I was miraculously given the opportunity to do my dream concept. And with two amazing artists, no less. The budget allowed for multiple shoot days, the video wasn't due for months, and Charlotte liked my idea. And so, I began to work on ideas, by diving right into my found photo folder. [...] I wrote scenes based on props and costumes we had access to. My friend, fellow director Josh Forbes has an amazing monster mask he used for his Myriad video, and I borrowed it for a bathtub scene. Various props are leftovers from other video shoots I've done.

So yes, it was supposed to be completely random. And any shot could have been anything else. But this video was my love letter to found photos. And I wanted to faithfully recreate some of my favorites. Which leads us to the works of William Hundley. Specifically, the "Skateboard on Cheeseburgers" shot.

I found that skateboard cheeseburger shot on some random website years ago. I thought it was funny so I threw it in my folder of found photos, and then saw it every time I looked through the pictures. I always loved it. It made absolutely no sense. I imagined it was the work of a skateboarding teen who took the photo as some elaborate inside joke. I imagined this guy going to McDonalds and buying 8 cheeseburgers, setting them up and taking a photo. And then going skateboarding.

That's why I loved this photo. No context, so I could make up my own. Had I known that it was from a real artist and part of a series for an art exhibit, I never would have included it in the video. [...] It was very sloppy and ignorant on my part to assume the photo was a found image. We should have looked into this and I regret that we didn't. I apologize. But my motivations for using it were the furthest thing from anything malicious. I couldn't tell you how happy I was to put a skateboard on 8 cheeseburgers. It was so fun to recreate a photo I loved in real life, to film it, and to look at the confused expressions from the rest of the crew. Oh, and I ate two of the cheeseburgers afterwards!

Now - onto the Floating Cloth photo. This one would fall under the category of images that were inspired by found photos, but not a direct recreation. I should have realized it was done by an artist. It didn't have the same kitschiness as the other shots. It was artistic and beautifully photographed. The mistake I made was that I looked at floating cloth picture and thought "that would look cool in a music video". [...] Now, what stinks is that two works by one artist were referenced in the video. I assure you, it's purely a coincidence - I had never been to Hundley's site before I saw the link on Antville. But it's easy to understand how he could have many of his works pop up on found photo sites. He's got great ideas. I can see why they've gotten spread around the Internet.

But the video is out, and all I can do is explain my motivations. [...] I just want to make it clear that there was no malicious intent. I pride myself on coming with original ideas, and the idea here - 50 random scenes, never repeating, inspired by found photos - was an idea that I thought was good and original. I still do. But when a few of those photos are clearly not found photos - the intention suffers. And then the entire piece, and all the time and work that goes into it - gets cheapened.

And so, I apologize to you, Hundley. I should have looked into this and contacted you before the video was released. [...] That's basically it. I could continue on about my opinion on the nature of the Internet, or what defines a found photo, or comparisons to other works that I think this is or isn't like. But everyone's got an opinion and, to some degrees, it's all subjective. I just wanted to give my side of the story. [...] So again: I'm not really trying to debate a person's opinion of the video; just trying to explain how this all came to be, and set things right with Hundley.

Thanks everyone. Keith Schofield.

(@kns201)

A série de comentários publicados pelos membros da comunidade Antville (da qual fazem parte William Hundley e Keith Schofield) no primeiro post de partilha de Heaven Can Wait demonstra uma aguda sensibilidade em relação a um dos tópicos mais estudados da penetração das plataformas digitais no quotidiano de um número crescente de utilizadores: a apropriação, manipulação e difusão (numa palavra: a propagação) de materiais pré-existentes por parte dos utilizadores para a criação dos seus próprios conteúdos mediáticos.

Já em 1986, Peter Wollen (1986, p. 169) chamava a atenção para o fato de a "era eletrônica" ampliar o alcance da noção de "idade de reprodução" de Walt Benjamin (autor que, de resto, é citado num dos comentários ao post): a reprodução, o pastiche e a citação estariam, pouco a pouco, deixando de ser meras práticas de parasitismo textual para se tornarem em formas constitutivas da textualidade mediática. Nicholas Bourriaud (2002, p. 12) refinaria esta assunção pós-moderna através da observação de que, desde os princípios da década de 1990, um número crescente de artistas interpreta, reproduz e torna a exibir como seus traba- 
lhos da autoria de terceiros. A denominada "arte da pós-produção" foi então conceitualizada pelo autor francês como uma resposta à crescente entropia da cultura global numa era da informação caracterizada por um aumento de oferta e pela crescente legitimação de formatos mediáticos outrora ignorados ou alvo de desdém (entre os quais se incluem, como é óbvio, os vídeos musicais). A "cultura de redação", uma noção similar definida pela produção de novos materiais a partir de um processo de edição de conteúdos pré-existentes (HARTLEY, 2008, p. 122), acabaria por tornar-se numa das características fundamentais da emergente paisagem mediática digital. A sua proliferação foi sobretudo causada por três desenvolvimentos ou inovações sociotecnológicas: a abundância de "matéria-prima" na Internet; a crescente disponibilização de software, muitas vezes grátis, que facilita a manipulação desses materiais (SERAZIO, 2008, p. 81); e a emergência de uma cultura participativa que esbate a tradicional fronteira que separava os produtores dos consumidores mediáticos (JENKINS, 2006, p. 3). Se o YouTube, por exemplo, funciona como uma fonte da qual brota criatividade é porque o portal suporta esta cultura participativa da web social e as suas práticas dominantes de colaboração cultural (STRANGELOVE, 2010, p. 187). Esta permanente evolução tem vindo a fomentar uma assinalável tensão entre, por um lado, as noções legais de propriedade intelectual e da defesa dos interesses econômicos dos autores, e, por outro, a promoção da criatividade e a garantia de liberdade de expressão (OLSON, 2004, p. 203). Tal situação, como é óbvio, não deixa indiferentes os utilizadores da web social e, em particular, os fãs do formato videomusical, em que se incluem os membros do Antville.

Porém, o que a análise deste caso de estudo sobretudo demonstra é que a fruição participativa dos fãs, quando operada em comunidade, produz não apenas práticas "forenses" que desencadeiam uma difusão vertical dos conteúdos mediáticos, como uma genuína forma de inteligência coletiva geradora de conhecimento, cuja massa, quando suficientemente crítica (e este é, definitivamente, o caso da comunidade Antville), emana uma força gravítica passível de se fazer sentir, direta ou indiretamente, um pouco por toda a web social. Apesar das acusações de plágio, Heaven Can Wait viria a ser legitimado pelos utilizadores da web e, em particular, pelos fãs do formato videomusical. Para além do já referido elevado número de visualizações alcançado pelos seus intertextos no Vimeo e no YouTube, o vídeo musical arrecadaria os prêmios de Melhor Vídeo do Ano e Melhor Direção Artística dos Antville Music Video Awards de $2009^{8}$ e viria a ser incluído na lista dos 40 melhores vídeos musicais do ano da Pitchfork ${ }^{9}$ e na dos vinte melhores da revista $\operatorname{Spin}^{10}$.

\section{Referências}

BOURRIAUD, N. Postproduction: culture as screenplay. how art reprograms the world. New York: Lukas \& Sternberg, 2002.

BRETON, A. Manifestes du Surréalisme. Paris: Folio Essais, 1994.

FISKE, J. The cultural economy of fandom. In: LEWIS, L. A. (ed.) The adoring audience: fan culture and popular media. London \& New York: Routledge, 1992. p. 30-49.

FISKE, J. Television culture. 2nd ed. London \& New York: Routledge, 2011.

GENETTE, G. Palimpsestes: la littérature au second degrée. Paris: Points, 1982.

HARTLEY, J. Television truths: forms of knowledge in popular culture. London: Blackwell, 2008.

HEAVEN can wait. Direção de: Keith Schofield. Intérpretes: Charlotte Gainsbourg \& Beck. 2009a. Disponível em: <http://vimeo.com/7703592 >. Acesso em: 16 abr. 2014.

HEAVEN can wait. Direção de: Keith Schofield. Intérpretes: Charlotte Gainsbourg \& Beck. 2009b. Disponível em: <http://youtu.be/CrWN0-MuK38>. Acesso em: 16 abr. 2014

\footnotetext{
${ }^{8}<$ http://videos.antville.org/stories/1958007/>. Acesso em: 16 abr. 2014.

${ }^{9}<$ http://tinyurl.com/as2s93d >. Acesso em: 16 abr. 2014.

${ }^{10}<$ http://www.spin.com/articles/20-best-videos-2009>. Acesso em: 16 abr. 2014.
} 
JENKINS, H. Convergence culture. New York: New York University Press, 2006.

LÉVY, P. Collective intelligence: mankind's emerging world in cyberspace. Cambridge: Perseus, 2007.

MITELL, J. To spread or to drill? Just TV Blog, 2009. Disponível em: <http://justtv.wordpress. com/2009/02/25/to-spread-or-to-drill/>. Acesso em: 16 abr. 2014.

OLSON, K. K. Copyright in cyberspace: protecting intellectual property online. In: GAUNTLETT, D.; HORSLEY, D. (eds.). Web.Studies. London: Edward Arnold, 2004. p. 195-203.

SERAZIO, M. The apolitical irony of generation mash-up: a cultural case study in popular music. Popular Music and Society, v. 31, n. 1, p. 79-94, Feb. 2008, 2008. Disponível em: <http://mediaediting.wikispaces.asu. edu/file/view/28552270.pdf>. Acesso em: 11 jul. 2014.

STRANGELOVE, M. Watching YouTube: extraordinary videos by ordinary people. Toronto: University Of Toronto Press, 2010.

SUROWIECKI, J. The wisdom of crowds. London: Abacus, 2004.

TAYLOR, J., BAKER, S., BENNETT, A. (eds.) Redefining mainstream popular music. New York: Routledge, 2013.

WOLLEN, P. Ways of Thinking about Music Video (and Postmodernism). Critical Quarterly, v. 28, n. 1/2, p. 167-70, 1986
Drilling on the social web: the Heaven Can Wait narrative on Antville

\section{Abstract}

Introduction: This paper aims a textual analysis of the participative fruition operated by Antville online music video fan community of Charlotte Gainsbourg and Beck's Heaven Can Wait (2009). Method: Ethnographic method in a grounded theory study. Results: The main results of the analysis are the framing of Antville members' praxis in the "forensic" fandom practices, which produce a rather eloquent form of collective intelligence fomented by "drillable" producerly features of the music video text. Conclusions: This "drillability" can be conceptualized as a complement of the most common spreadable practices of diffusion on the social web (dissemination and propagation).

\section{Keywords}

Social web. Music video. Web drillability. Web spreadability. Fandom.

\section{Agradecimentos:}

Este artigo foi desenvolvido no âmbito de um projeto de investigação que se beneficiou de uma bolsa de doutoramento atribuída pela Fundação para a Ciência e Tecnologia/Ministério da Educação e Ciência - Portugal. (Referência SFRH/ $\mathrm{BD} / 68728 / 2010)$.

Recebido em 5 maio 2014

Aceito em 11 junho 2014

\section{Sobre o autor:}

\section{João Pedro da Costa}

Doutor em Informação e Comunicação em Plataformas Digitais - FLUP e UA. Licenciado em Línguas e Literaturas Modernas - FLUP.

joaopedrodacosta@gmail.com

Como citar este artigo:

COSTA, J. P. da. A difusão vertical na web social: o caso de "Heaven Can Wait" no Antville. AtoZ: novas práticas em informação e conhecimento, Curitiba, v. 3, n. 1, p. 12-22, jan./jun. 2014. Disponivel em: <http://www.atoz.ufpr.br>. Acesso em: 